\title{
Effects of pre-ozonation and chemical coagulation on the removal of turbidity, color, TOC, and chlorophyll a from drinking water
}

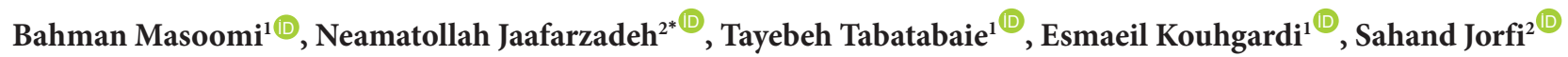 \\ ${ }^{1}$ Department of Environmental Engineering, Bushehr Branch, Islamic Azad University, Bushehr, Iran \\ ${ }^{2}$ Environmental Technologies Research Center, Ahvaz Jundishapur University of Medical Sciences, Ahvaz, Iran
}

\begin{abstract}
Background: Ozone can be used as a single technology or in combination with other processes to improve the coagulation- flocculation or biodegradability in order to remove pollutants in natural water treatment.

Methods: In this study, the effects of pre-ozonation with coagulant substances on the quality parameters of drinking water were investigated using humic acid, kaolin, clay, and green algae in a pilot scale. This study was conducted under laboratory conditions (at both acidic and alkaline $\mathrm{pH}$ in different dosages of ozone and coagulant at ozone contact time with simulated water sample (5-20 minutes) in different scenarios).

Results: The highest removal efficiency of parameters in the state of pre-ozonation alone and preozonation with a coagulant was observed at contact time of 20 minutes, ozone dosage of $5 \mathrm{~g} / \mathrm{h}$, coagulant dosage of $25 \mathrm{mg} / \mathrm{L}$, at alkaline $\mathrm{pH}$ along with a decrease in temperature. So that, the average removal rate of turbidity, total organic carbon (TOC), color, and chlorophyll a in contact time of 20 minutes was $76.9 \%, 52.8 \%, 66.6 \%$, and $85 \%$, respectively. However, compared to ozonation under similar conditions, the reduction in turbidity, TOC, color, and chlorophyll a was $36.13 \%, 24.4 \%, 32.13 \%$, and $79.6 \%$, respectively. Also, it was revealed that pre-ozonation with coagulant could effectively improve the removal of parameters.

Conclusion: However, since pre-ozonation can be effectively used to improve the coagulation efficacy in the drinking water treatment, the pre-ozonation combined with coagulation is proposed as an alternative to conventional coagulation to improve the process of drinking water treatment plant. Keywords: Pilot projects, Drinking water, Water quality, Ozone, Flocculation, Kaolin, Clay, Green algae Citation: Masoomi B, Jaafarzadeh N, Tabatabaie T, Kouhgardi E, Jorfi S. Effects of pre-ozonation and chemical coagulation on the removal of turbidity, color, TOC, and chlorophyll a from drinking water. Environmental Health Engineering and Management Journal 2019; 6(1): 53-61. doi: 10.15171/ EHEM.2019.06.
\end{abstract}

\section{Article History:}

Received: 15 December 2018

Accepted: 4 February 2019

ePublished: 26 February 2019

\section{Introduction}

To purify potable water, a combination of chemical and physical processes is used (1). The most commonly used processes in the water treatment plant include filtration, flocculation, sedimentation, and disinfection for surface water (2). The physical characteristics (turbidity, color, temperature, and electrical conductivity), chemical characteristics (total dissolved oxygen, $\mathrm{pH}$, and alkalinity), and biological characteristics of water are important factors that determine the quality of drinking water (3-6). High turbidity of the water is due to the presence of colloidal materials, which provide adsorption sites for chemicals that may be harmful or cause undesirable taste and odors (7). Generally, dissolved organic matters such as tannic, humic, and fulvic acids make natural color in the water $(8,9)$. Van Staden showed that natural color of water can be removed by direct filtration, conventional treatment or activated carbon, and ozone as an efficient oxidant is often used for removal of oxidative color (10). $\mathrm{pH}$ is an important chemical indicator of water. Temperature is also an important parameter because of its impact on the water chemistry (11). Turbidity and color are indirectly related to temperature and temperature affects coagulation. The performance of coagulation is temperature-dependent, and the optimum $\mathrm{pH}$ for coagulation depends on the temperature changes (12). Coagulation and flocculation are considered as the basic processes in the most water treatment plants (13). Flocculation by the addition of 
synthetic or natural polymers, after the complete mixing step, permits transformation of micro-flocs into larger flocks that can be removed by the conventional water treatment processes (14). The amount of coagulant that was added to the water sample is an important factor in destabilizing colloidal particles in a given water sample (15). For every coagulant, there exists an "optimal dosage" for specific water chemistry and composition at which the coagulation of particles is optimized $(15,16)$. The amount of chemical disinfectants is important since they can react with organic and inorganic precursors and produce disinfection byproduct (DBP) in the case of consuming more than the required dosage (17). Ozone is a powerful oxidizing agent and is an effective disinfectant in water without creating DBPs, which are formed in water with chlorine (18). Also, ozone is used for the removal of organic materials creating color in drinking water, and oxidation iron and manganese salts (19). Alum is used as a coagulant in water treatment processes, pre-ozonation increases the removal of total organic carbon (TOC), turbidity, and dissolved organic carbon (DOC) ( 0.5 to $0.8 \mathrm{mg} / \mathrm{L}$ ozone) under the conditions tested (20). Studies have shown that ozonation transforms natural organic matter from humic material to non-humic fractions $(21,22)$. Ozone can be used as a single technology or in combination with other processes to improve the coagulation-flotation or biodegradability in order to remove pollutants in natural water treatment (23). Torabian et al evaluated the effect of pre-ozonation on the TOC removal in surface water treatment. The results showed that pre-ozonation not only supplied the required material to remove TOC, but also improved TOC removal (24). Generally, with increasing ozone dosage at different coagulant dosages slightly, TOC removal increased but at average coagulant dosages, it was decreased (25). Masoomi et al evaluated the performance of pre-ozonation in removing turbidity and TOC. He found that the average efficiency of the ozonation in the TOC removal with an average ozone concentration of 3 $\mathrm{kg} / \mathrm{h}$ and a contact time of 18 minutes was $20.52 \%$, and the average turbidity removal efficiency was $61 \%$ (26). Considering all the above-mentioned studies, the present study aimed to assess the effects of pre-ozonation alone and pre-ozonation with a coagulant on the removal of quality parameters (turbidity, color, chlorophyll a, and TOC) of drinking water, which was conducted in a pilot scale on the water entering the Koohsabz drinking water treatment plant, Fars.

\section{Materials and Methods}

Water samples and materials

In order to simulate turbidity and TOC of samples, clay, humic acid (95\%) in powder form, and kaolinite were added to the raw water. To simulate chlorophyll a and watercolor during pre-ozonation alone and pre-ozonation with Coagulant, green algae (Chlorella vulgaris) were used. These algae were prepared from Ponds to drain downstream of the Doroodzan dam. In order to supply nitrate required for algae, sodium nitrate $(\mathrm{NaNO} 3)$ was added. Aluminum sulfate (Kimia Materials Company) was used as a coagulant. The required ozone was supplied by an ozone generator (OPW27 model) with a nominal capacity of $5 \mathrm{~g} / \mathrm{h}$, equipped with an air pump.

\section{Method of analysis}

The study was conducted in a pilot and laboratory scale on a water sample entering the Koohsabz drinking water treatment plant in July 2017. This plant is located in Fars province, the South of Iran, at a distance of $12 \mathrm{Km}$ from Marvdasht city, and near Koohsabz village with a longitude of $52^{\circ} 41^{\prime} 29.16^{\prime \prime} \mathrm{E}$ and $29^{\circ} 55^{\prime} 16.79^{\prime \prime} \mathrm{N}$.

First, the raw water with turbidity of 9.8 FTU was simulated using clay and kaolin, clay was passed through a standard sieve (No 200), that the turbidity reached 21.8 FTU. Then, desired TOC concentration $(9.5 \mathrm{mg} / \mathrm{L})$ was simulated by adding humic acid in powder form. Desired chlorophyll a concentration and watercolor (1.6 $\mathrm{mg} / \mathrm{L}$ and 19.6 TCU) were simulated by adding green algae (Chlorella vulgaris) in algae solution form. In order to supply nitrate required for algae to the algae solution of $\mathrm{NaNO} 3$ was added. Aluminum sulfate used in the Koohsabz drinking water treatment plant was used as a coagulant in this study. Standard jar test procedures were used to evaluate aluminum sulfate requirements and the primary water quality parameters. The aluminum sulfate dosage selected for the removal of parameters (TOC, turbidity, color, and chlorophyll a) ranged from 5 to 25 $\mathrm{mg} / \mathrm{L}$. To study the effects of ozonation, the ozone dosage of 1 to $5 \mathrm{~g} / \mathrm{h}$ and ozone contact time of 5 to 20 minutes were selected. Figure 1 illustrates a schematic plan of the reactor used in this study. Water temperature and $\mathrm{pH}$ influence the decomposition rate of ozone, and decrease of temperature increased dissolved ozone concentrations. The performance of coagulation is temperaturedependent and the optimum $\mathrm{pH}$ for coagulation depends on the temperature changes. Therefore, the effects of water temperature and $\mathrm{pH}$ changes in the removal of parameters in the process of ozonation alone and with coagulant material were also assessed in this study. The $\mathrm{pH}$ of water was adjusted to $4-8.6$ by hydrochloric acid and sodium hydroxide. Finally, about $20 \mathrm{~L}$ of the sample solution was prepared based on the characteristics

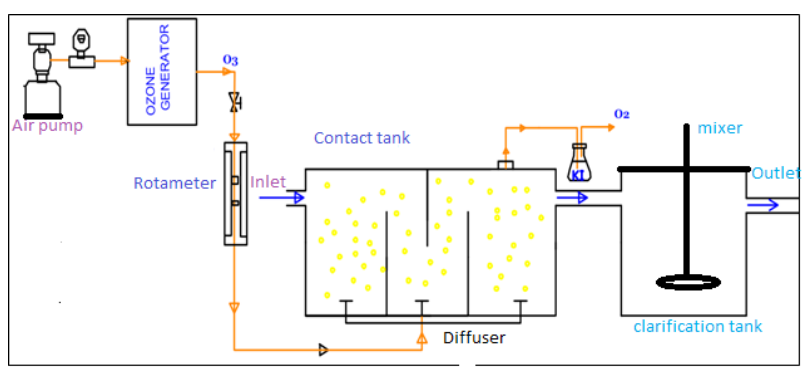

Figure 1. A schematic plan of experimental pre-ozonation. 
Table 1. Characteristics of simulated water samples to study the effect of ozonation along with coagulant in removing water quality parameters

\begin{tabular}{lcccccc}
\hline Parameter & $\mathrm{pH}$ & Temperature & Chlorophyll A $\left(\mathrm{mg} / \mathrm{m}^{3}\right)$ & Turbidity (FTU) & Color (TCU) & TOC (mg/L) \\
\hline Amount & 7.6 & 21.9 & 1.6 & 21.8 & 19.6 & 9.5 \\
\hline
\end{tabular}

indicated in Table 1. In the next step, the effects of the pre-ozonation process alone and with coagulant on the parameters of turbidity, color, chlorophyll a, and TOC were investigated. Also, to determine the effects of alum on parameters, different doses of alum from 5 to $25 \mathrm{mg} / \mathrm{L}$ were added to the water sample taken at $\mathrm{pH} 7$ and after the coagulation and flocculation process, the rate of change of parameters was evaluated at different doses. The required ozone was supplied by an ozone generator (OPW 27) with a nominal capacity of $5 \mathrm{~g} / \mathrm{h}$ using an air pump. In this study, a 20 -L glass container $(40 \times 25 \times 20 \mathrm{~cm})$ was used to conduct the ozonation process. The entire ozone reactor was divided into four cells with three baffles of 20 $\times 20 \mathrm{~cm}$. The first baffle was selected with a cell wall of about $13 \mathrm{~cm}$, and other three cells were selected with a distance of $9 \mathrm{~cm}$. The generated ozone in the reactor was injected from the floor into the reactor by four diffusers in the form of ultra-fine bubbles (Figure 1). The ozonation process of simulated water samples was conducted on simulated water samples in different scenarios at different contact times $(5,10,15$, and 20 minutes) and different doses of ozone (1 to $5 \mathrm{~g} / \mathrm{h}$ ). Then, $\mathrm{pH}$ of the samples was calibrated daily using Metrohm device (Switzerland, Model 830) and standard buffer solutions. TOC was measured by a spectrophotometer (DR 4000) using method 10129, and the turbidity and chlorophyll a were monitored using Algaturch device. Finally, the color was measured according to the standard method $2120 \mathrm{C}$ using an spectrophotometer (HACH DR-5000 model), having 10-mm absorption cells, a narrow (10-nm or less) spectral band, and an effective operating range from 400 to 700 nm (27).

\section{Results}

In order to examine the effects of pre-ozonation alone and with coagulant (aluminum sulfate) on water quality parameters, the turbidity, color, and TOC were simulated using clay, kaolin, and humic acid in several stages. Table 1 indicates the average of simulated water quality parameters in four scenarios.

In order to evaluate the pre-ozonation effects on water quality parameters alone and with coagulant (aluminum sulfate), the turbidity, color, and TOC were simulated using clay, kaolin, and humic acid in several steps. The transferred ozone dosage, contact time, the amount of coagulant changes in each scenario, and the rate of change were accordingly evaluated. The results obtained from the review of the variation of the parameters are illustrated in Figure 2. As shown in this figure, the trend of change of water quality parameter changed in the ozonated water with coagulant substances (chlorophyll a, color, turbidity, and TOC) at different doses of ozone with different doses of coagulant ( 5 to $25 \mathrm{mg} / \mathrm{L}$ ) at different contact time. As shown in this figure, by increasing the time of ozone contact with water and increasing the injectable ozone dose and coagulant material to the experimental pre-ozonation pilot, the trend of change of parameters was also increased. In this case, the trend of changes of $\mathrm{pH}$ increased but the trend of changes of temperature decreased.

Evaluation of the removal efficiency of parameters in the second state (pre-ozonation + coagulant)

Figure $3 \mathrm{~A}$ shows the removal efficiency of the parameters in the simulated sample studied in 5 minutes at different doses of ozone ( 1 to $5 \mathrm{~g} / \mathrm{h}$ ) with various doses of coagulant ( 5 to $25 \mathrm{mg} / \mathrm{L}$ ) at different $\mathrm{pHs}$ and temperatures. The average removal rate in turbidity, TOC, color, and chlorophyll a was $26.79 \%, 5.7 \%, 11.3 \%$, and $14.5 \%$, respectively. In this case, compared with ozonation alone, the rate of reduction of the parameters was $15.04 \%, 0.84 \%, 5.4 \%$, and $40.4 \%$, respectively. Further, by increasing the contact time of ozone with water along
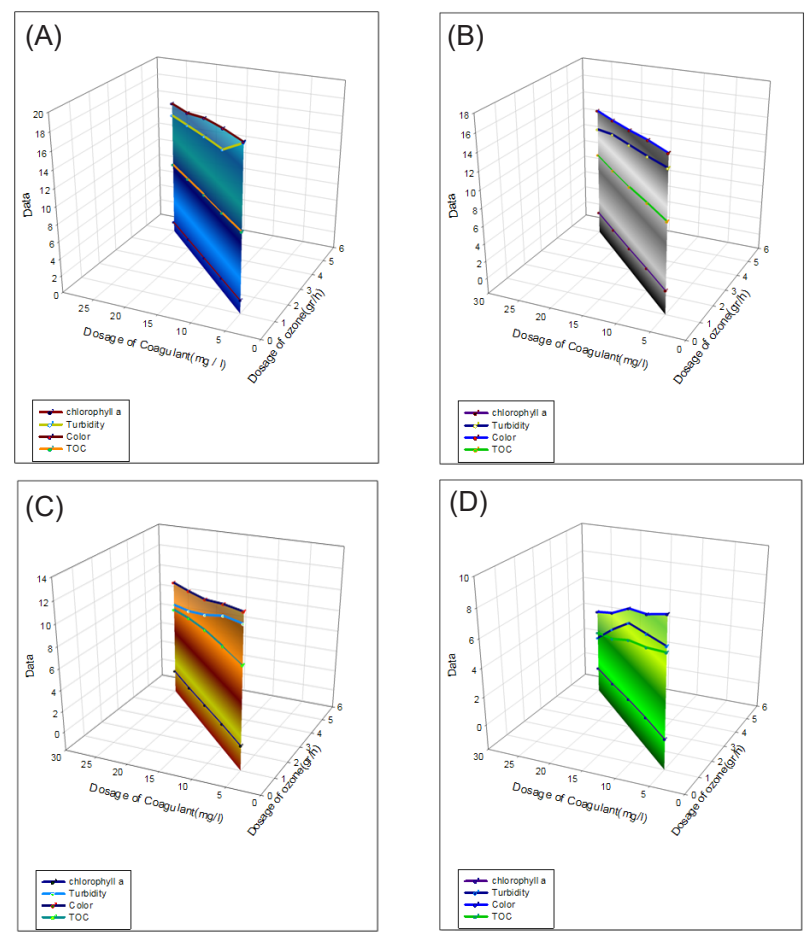

Figure 2. The trend of changes of quality parameters (chlorophyll a, color, turbidity, and TOC) in the ozonated water with coagulant materials at different doses of ozone with different doses of coagulant ( 5 to $25 \mathrm{mg} / \mathrm{L}$ ) at different contact time (A: $5 \mathrm{~min}, \mathrm{~B}: 10 \mathrm{~min}, \mathrm{C}: 15 \mathrm{~min}$, and D: $20 \mathrm{~min}$ ). 
with the injection of aluminum as coagulant at different doses, the removal efficiency of turbidity, TOC, and color parameters increased compared to the ozonation alone while the removal efficiency of chlorophyll a decreased. Furthermore, it was revealed that an increase in ozone dose $(5 \mathrm{~g} / \mathrm{h})$, along with an increase in the coagulant dose (25 mg/L), contact time (20 minutes), and $\mathrm{pH}$ (alkaline $\mathrm{pH})$ has the best efficiency in removing the parameters. Figure $3 \mathrm{~B}$ shows the removal efficiency of the parameters in the simulated water sample studied in 10 minutes at different doses of ozone ( 1 to $5 \mathrm{~g} / \mathrm{h}$ ) with various doses of coagulant ( 5 to $25 \mathrm{mg} / \mathrm{L}$ ) at different $\mathrm{pHs}$ and temperatures. The average removal rate of turbidity, TOC, color, and chlorophyll a was $41.7 \%, 13.5 \%, 26.3 \%$, and $46.9 \%$, respectively. In this case, compared with the ozonation alone, the rate of reduction of the parameters was $22.28 \%, 4 \%, 12.24 \%$, and $57.8 \%$, respectively.

Figure $3 \mathrm{C}$ shows removal efficiency of the parameters in the simulated water sample studied in $15 \mathrm{~min}$ at different doses of ozone ( 1 to $5 \mathrm{~g} / \mathrm{h}$ ) with various doses of coagulant (5 to $25 \mathrm{mg} / \mathrm{L}$ ) at different $\mathrm{pHs}$ and temperatures. The average removal rate of turbidity, TOC, color, and chlorophyll a was $57.3,20.4,44.8$, and $68.8 \%$, respectively. In this case, compared with ozonation alone, the rate of reduction of the parameters was $29.62 \%, 10.52,20.44 \%$, and $66.56 \%$, respectively.
Figure 3D shows removal efficiency of the parameters in the average removal rate of some parameters such as turbidity, TOC, color, and chlorophyll a during a 20-minute contact with an ozone dose of $5 \mathrm{~g} / \mathrm{h}$ and coagulant dose of $25 \mathrm{mg} / \mathrm{L}$ at different $\mathrm{pHs}$ and temperatures, was $76.9 \%$, $52.8 \%, 66.6 \%$, and $85 \%$, respectively. However, compared to the ozonation with similar conditions, the reduction in turbidity, TOC, color, and chlorophyll a was $36.13 \%$, $24.4 \%, 32.13 \%$, and $79.6 \%$, respectively. While the effect of alum in the removal of turbidity, color, TOC, and chlorophyll a in the same state at $\mathrm{pH} 7$ and doses of 5 to $25 \mathrm{mg} / \mathrm{L}$, was $20 \%, 18.4 \%, 7.4 \%$, and $25.5 \%$, respectively. Furthermore, the effect of temperature and $\mathrm{pH}$ on the parameters removal was investigated in the present study. The results indicated that the removal efficiency of parameters increased by decreasing the temperature. The $\mathrm{pH}$ changed from acidic state $(\mathrm{pH}=4)$ in the first scenario to an alkaline state $(\mathrm{pH}=8.6)$ in the fourth scenario. Thus, the removal efficiency of the parameters in the fourth scenario was higher than that in the other scenarios. The removal efficiency of chlorophyll A, color, turbidity, and TOC of the simulated water relative to the dosage of injectable ozone, the coagulant dosage, $\mathrm{pH}$, and temperature changes at contact time of 5 to 20 minutes is shown in Figure 3A-D. As shown in this figure, by increasing the time of ozone contact with water

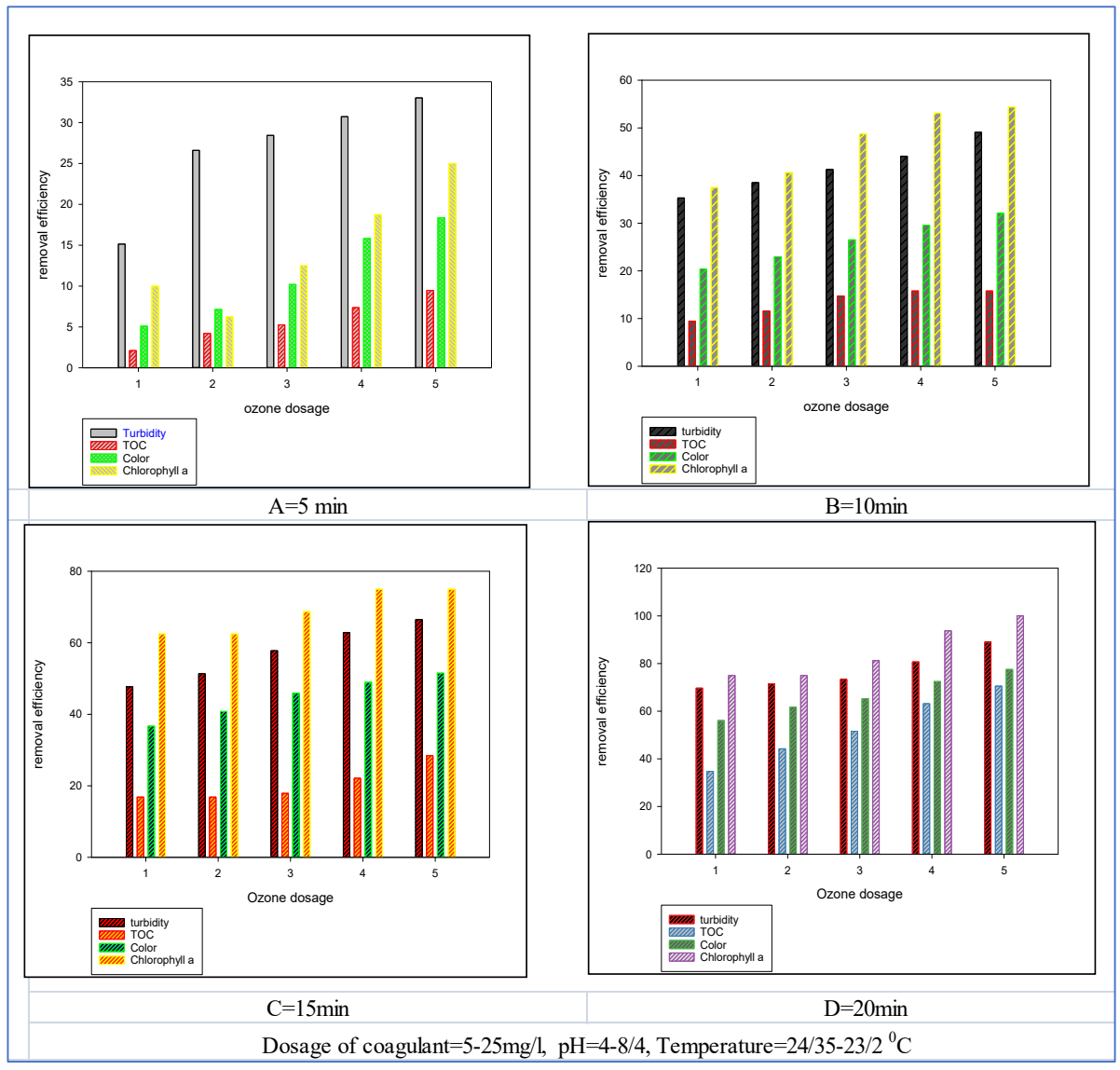

Figure 3. The trend of changes of the removal efficiency of turbidity, TOC, color, and chlorophyll a relative to the dose of ozone injected and contact time. 
and increasing the injectable ozone dose and coagulant material to the experimental pre-ozonation pilot, the removal efficiency of parameters increased. In this case, the trend of changes of $\mathrm{pH}$ increased but it was decreased for temperature. Therefore, it can be said that temperature, $\mathrm{pH}$, dose of oxidant and coagulant, and contact time, were important operational factors for the quality of the treated water, and pre-ozonation with coagulant could effectively improve the removal of parameters.

\section{Statistical analysis of results}

Statistical analysis was performed to determine the changes in parameters at different times of ozone ( 1 to 5 $\mathrm{g} / \mathrm{h}$ ) contact with coagulant ( 5 to $25 \mathrm{mg} / \mathrm{L}$ ) by SigmaPlot 12.5 software. The linear regression of laboratory data indicated that all results were significant at confidence level of $95 \%$. Figure 4 and Table 2 indicate the results of the statistical analysis for the changes in parameters with injected ozone $(1 \mathrm{~g} / \mathrm{h})$ and coagulant $(5 \mathrm{mg} / \mathrm{L})$ at different contact times (5 to 20 minutes). In addition, Table 3 demonstrates the results of the statistical analysis for changes in parameters with injected ozone $(5 \mathrm{~g} / \mathrm{h})$ and coagulant $(25 \mathrm{mg} / \mathrm{L}$ ) at different contact times ( 5 to 20 minutes). Based on the results, the $\mathrm{R}$-squared value and $\mathrm{P}$-value of the parameters ranged from $<0.05$ to 1 (200 repetitions), which indicates the significance of the parameters. Furthermore, in order to validate the obtained data, 95\% confidence level was used from the statistical analysis. As shown in Figure 5, all of the data are within the $95 \%$ confidence level.

\section{Discussion}

In this study, to evaluate the effects of pre-ozonation alone and pre-ozonation with coagulant, the water samples were

Table 2. Statistical analysis of the changes in parameters by the injection of ozone $(1 \mathrm{~g} / \mathrm{h})+$ coagulant $(5 \mathrm{mg} / \mathrm{L})$ at different contact times

\begin{tabular}{lccccc}
\hline Parameters & $\mathbf{R}$ & $\mathbf{R}^{\mathbf{2}}$ & $\boldsymbol{P}$ value & Iterations & Number of iterations performed \\
\hline TOC $(\mathrm{mg} / \mathrm{L})$ & 0.9746 & 0.9533 & 0.0236 & 200 & 22 \\
Turbidity (FTU) & 0.9979 & 0.9959 & 0.0021 & 200 & 37 \\
Color (TCU) & 0.9985 & 0.9971 & 0.0015 & 200 & 24 \\
Chlorophyll A $\left(\mathrm{mg} / \mathrm{m}^{3}\right)$ & 0.9759 & 0.9524 & 0.0241 & 200 & 1 \\
\hline
\end{tabular}
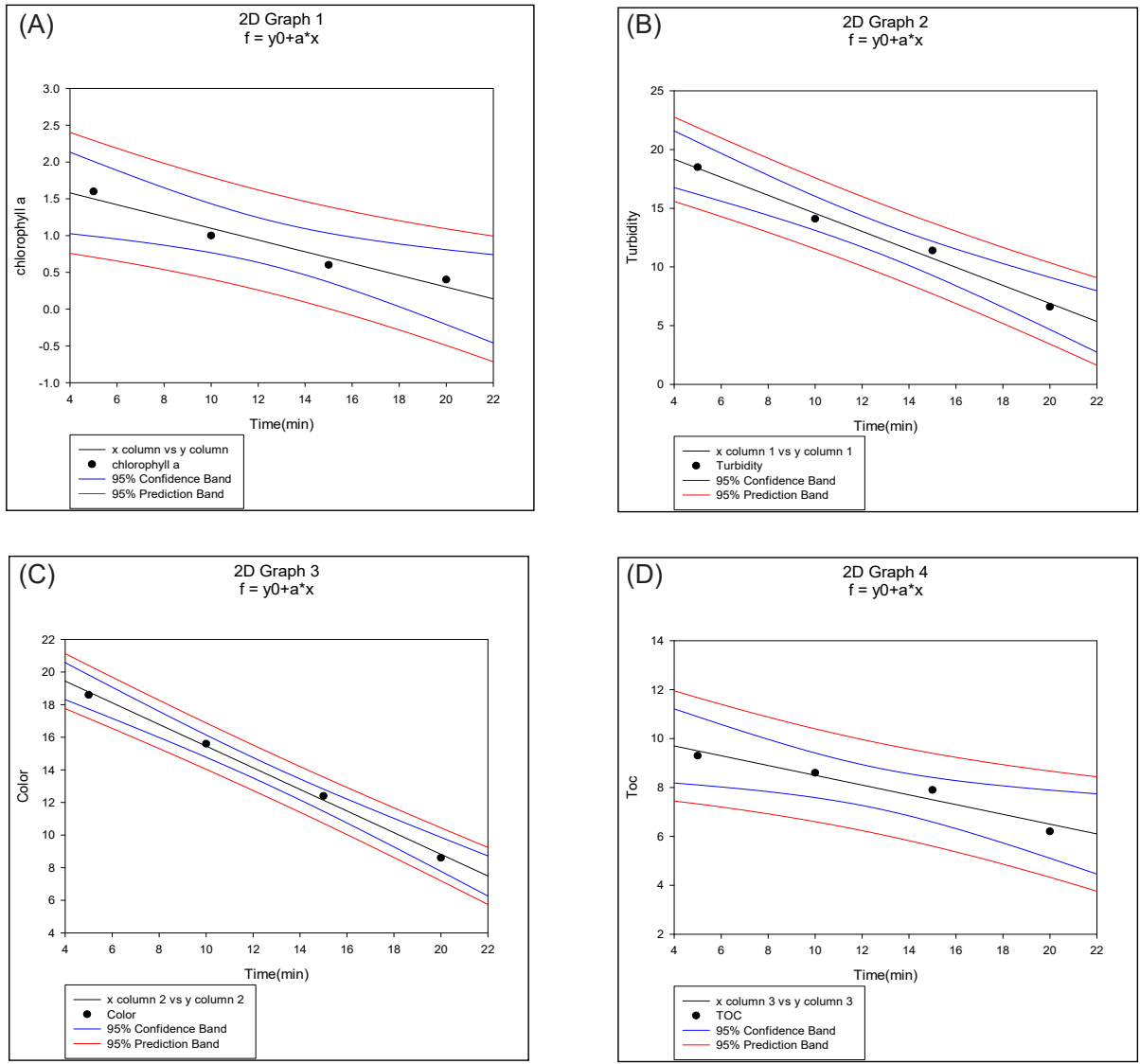

Figure 4. Statistical analysis of the changes in turbidity, TOC, and color in terms of contact time by the injection of ozone (1 $\mathrm{g} / \mathrm{h})$ with coagulant (5 mg/L) (A: chlorophyll a, B: Turbidity, C: Color, D: TOC). 
Table 3. Statistical analysis of the changes in parameters by the injection of ozone $(5 \mathrm{~g} / \mathrm{h})+$ coagulant $(25 \mathrm{mg} / \mathrm{L})$ at different contact times

\begin{tabular}{lccccc}
\hline Parameters & $\mathbf{R}$ & $\mathbf{R}^{\mathbf{2}}$ & $\boldsymbol{P}$ value & Iterations & Number of iterations performed \\
\hline TOC $(\mathrm{mg} / \mathrm{L})$ & 0.9831 & 0.9665 & 0.0169 & 200 & 39 \\
Turbidity (FTU) & 0.9972 & 0.9944 & 0.0028 & 200 & 77 \\
Color (TCU) & 0.9910 & 0.9821 & 0.0090 & 200 & 200 \\
Chlorophyll A $\left(\mathrm{mg} / \mathrm{m}^{3}\right)$ & 0.9978 & 0.9956 & 0.0022 & 10 \\
\hline
\end{tabular}
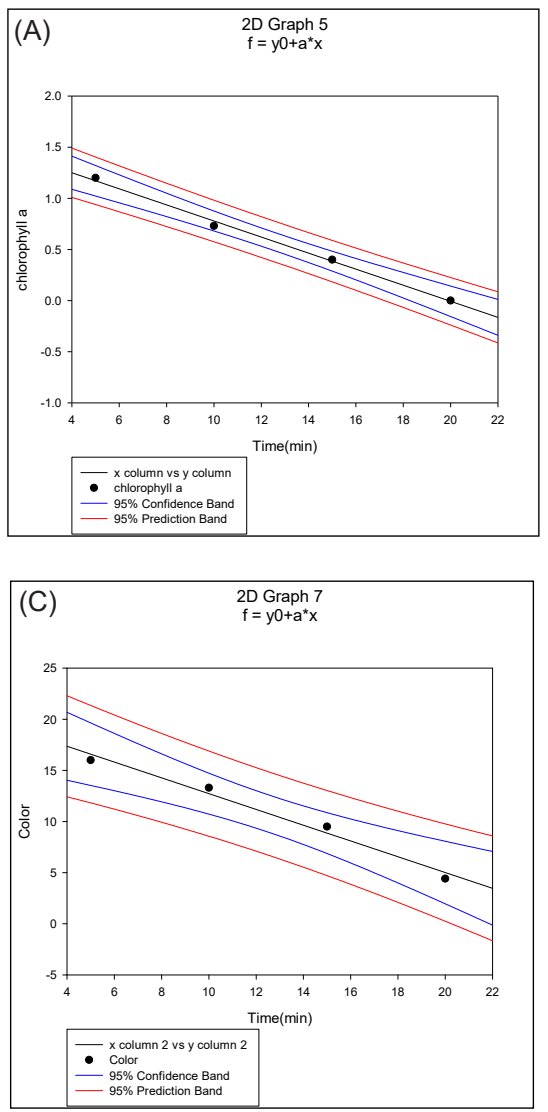
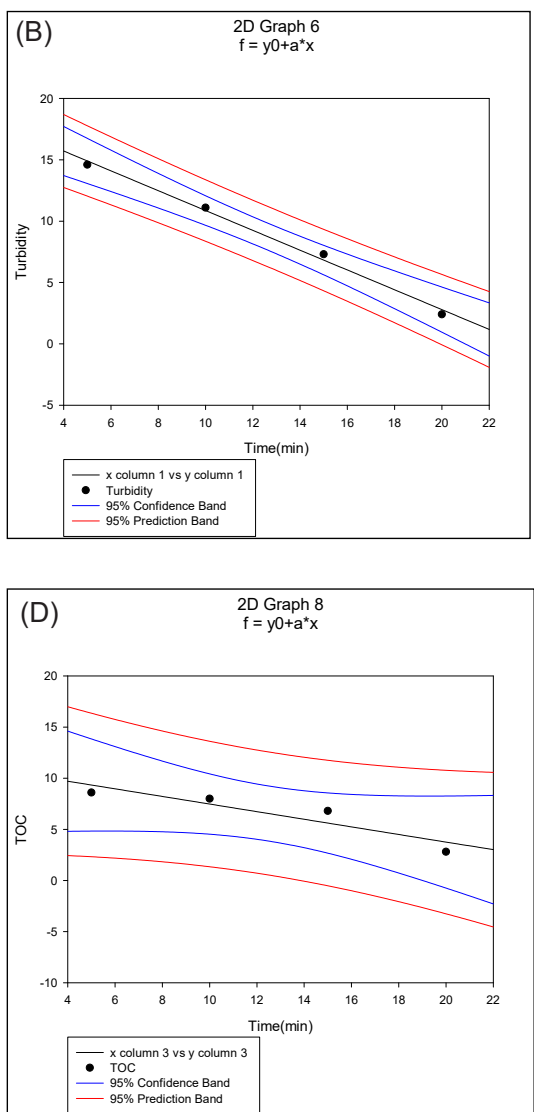

Figure 5. Statistical analysis of variation of turbidity, TOC, color, and chlorophyll in terms of contact time by the injection of ozone (5 g/h) + coagulant (25 mg/L) (A: chlorophyll a, B: Turbidity, C: Color, D: TOC).

evaluated under various conditions. Various factors such as ozone dose, ozone contact time with water, coagulant dose, temperature, and $\mathrm{pH}$ are considered as some of the factors influencing the pre-ozonation process. Water temperature and $\mathrm{pH}$ influence the decomposition rate of ozone and lower temperature permits higher dissolved ozone concentrations. In this study, the temperature decreased in the pre-ozonation alone and with coagulant. Considering higher reduction of the parameters in the fourth scenario compared to the former ones, it can be said that the ozone contact time with water and temperature change affect the ozonation process significantly. The $\mathrm{pH}$ value influences the mechanism of the reaction and the type of created products. The results showed that different doses of ozone are needed at different pHs. The highest removal efficiency of water quality parameters occurred due to $\mathrm{OH}^{0}(\mathrm{pH}=8.6)$, as the main initiator of ozone decomposition. Therefore, an increase in $\mathrm{pH}$ increases the ozone decomposition rate and affects the reaction of ozone oxidation with other elements. More radicals would be produced consequently if the amount of ozone decomposition increases under alkaline conditions (28). In addition, the results demonstrated that the high removal efficiency of water quality parameters occurred in the presence of hydroxyl radicals (alkaline $\mathrm{pH}$ ), which is consistent with the results of the previous studies $(28,29)$. A study by Sumegová et al showed that after 10 minutes of ozonation at $\mathrm{pH}=11$, the concentration of methylene blue was significantly decreased. The results indicated that the highest performance was observed at alkaline $\mathrm{pH}$ (29). Contact time is one of the basic parameters in designing an ozonation unit contactor. Increasing contact time will have a positive effect on the ozonation function, which was observed well in the experimental pre-ozonation pilot. The 
results showed that by increasing ozone doses and contact time, the level of residual ozone in the system decreased and the removal efficiency of the parameters increased. Application of ozone before enhanced coagulation, can sufficiently change to remove low molecular weight and non-humic fractions. Also, the results showed that the addition of ozone before alum coagulation increased TOC removal. The removal efficiency of TOC in the pre-ozonation at contact time of 5 to 20 minutes, was $0.84 \%, 4 \%, 10.52 \%$, and $24.4 \%$ respectively, and in the pre-ozonation with coagulant at contact time of 5 to 20 minutes, was $5.7 \%, 13.5 \%, 57.3 \%$, and $76.9 \%$, respectively. While the effects of alum in the removal of TOC in the same state with $\mathrm{pH} 7$ at ozone doses of 5 to $25 \mathrm{mg} / \mathrm{L}$, was $7.4 \%$. Thus, the results indicated that the removal efficiency of TOC was more than that of ozonation alone in the case of using ozone with the coagulant. Therefore, pre-ozonation is used to enhance coagulation and clotting in water treatment. The results of the present study confirm the results of the previous studies. A study by Mamba et al showed the TOC reduction from 14.53 to $10.40 \mathrm{mg} / \mathrm{L}$ in the source water after ozonation (30). Pryor et al found that ozone in the water treatment plant has little or no effect on the TOC removal (19). Yan et al reported that the pre-ozonation has an effect on coagulation and depends on the dosage of ozone, coagulant type, and water contamination (31). If an alum as a coagulant is used, as in the conditions tested, pre-ozonation prevents the removal of turbidity and DOC. The results showed that pre-ozonation leads to better coagulation with reduced surface charge of particulates (20). The removal efficiency of turbidity in the pre-ozonation alone at contact time of 5 to 20 minutes, were $15.04 \%, 22.28 \%, 29.62 \%$, and $36.13 \%$, respectively, and in the pre-ozonation with coagulant at contact time of 5 to 20 minutes, were $26.8 \%, 41.7 \%, 57.3 \%$, and $76.9 \%$, respectively. While the effects of alum in the removal of turbidity in the same state with $\mathrm{pH} 7$ at doses of 5 to $25 \mathrm{mg} / \mathrm{L}$, was $20 \%$. Amirsardari et al, reported that pre-ozonation by alum in acidic conditions reduces turbidity to $30 \%$ (32). Ozonation decreases the color in water by breaking the polymers and organic materials in the water. By increasing ozone doses, the color removal in water is approximately $80 \%$ (33). The removal efficiency of color in the pre-ozonation alone at contact time of 5 to 20 minutes, were $5.4 \%, 12.24 \%, 2.44 \%$, and $32.13 \%$, respectively, and in the pre-ozonation with coagulant at contact time of 5 to 20 minutes, was $11.3 \%, 26.3 \%, 44.8 \%$, and $66.6 \%$, respectively. While the effects of alum in the removal of color in the same state with $\mathrm{pH} 7$ at doses of 5 to $25 \mathrm{mg} / \mathrm{L}$, was $18.4 \%$. Basak et al found that at ozone contact time of $10 \mathrm{~min}$, color and DOC are removed by 80 and $65 \%$, respectively (34). The removal efficiency of chlorophyll a in the pre-ozonation alone at contact time of 5 to 20 minutes, was $40.4 \%, 57.8 \%, 66.56 \%$, and $79.6 \%$, respectively, and in the pre-ozonation with coagulant at contact time of 5 to 20 minutes, was $14.5 \%, 46.9 \%$,
$68.8 \%$, and $85 \%$, respectively. While the effects of alum in the removal of chlorophyll a in the same state with $\mathrm{pH}$ 7 at doses of 5 to $25 \mathrm{mg} / \mathrm{L}$, was $25.5 \%$. Thus, the results of the present study confirm the results of the previous studies. Morrison et al reported that pre-ozonation and medial ozonation do not have sufficient effects on $\mathrm{pH}$, EC, DOC, and TOC. Furthermore, chlorophyll a, total chlorophyll, and the spectral absorption coefficient at $254 \mathrm{~nm}$ (SAC254) do not change significantly under the influence of pre-ozonation, but it is strongly influenced by the medial ozonation (19). The results of a study by Geldenhuys et al showed that ozonation by sedimentation and filtration improved the physical removal of algae by 17.7 and $17.0 \%$, respectively, but ozonation alone could not decrease the total chlorophyll values much (35).

\section{Conclusion}

The results indicated that contact time, temperature, $\mathrm{pH}$, ozone dosage, and water quality are among the factors affecting the pre-ozonation process alone and with coagulation process of water. Temperature plays a major role in the ozonation process. The results indicated that the removal efficiency of water quality parameters was increased by decreasing the temperature because ozone solubility increases by decreasing the temperature in water. The removal efficiency of the parameters in scenario 4 was higher than that in the other scenarios. It can be said that alkaline $\mathrm{pH}$ had significant effect on the process of ozonation because an increase in the $\mathrm{pH}$, leads to an increase in the ozone decomposition rate due to the production of highly-reactive free radicals such as radical hydroxyl $(\mathrm{OH})$. The results related to the removal efficiency of water quality parameters in the pre-ozonation alone and with coagulant, showed that the highest removal efficiency of parameters was observed at contact time of $20 \mathrm{~min}$, ozone dosage of $5 \mathrm{~g} / \mathrm{h}$, coagulant dosage of $25 \mathrm{mg} / \mathrm{L}$, at alkaline $\mathrm{pH}$ along with a decrease in temperature. In this case, in the pre-ozonation process alone, the percentages of turbidity, TOC, color, and chlorophyll were $36.13 \%, 24.4 \%, 32.13 \%$, and $79.8 \%$, respectively. The results showed that the lowest removal efficiency belonged to TOCs $(24.4 \%)$ and the highest one belonged to chlorophyll a $(79.8 \%)$. According to the analyses, it was revealed that alum $(7.4 \%)$ and preozonation alone has the least effect on the TOC removal (24.4\%). Generally, it can be concluded that pre-ozonation alone cannot be so effective in removing TOC. The removal efficiency of turbidity parameters, TOC, color, and chlorophyll a in the state of the pre-ozonation with coagulant in the optimal conditions, was $76.9 \%, 52.8 \%$, $66.6 \%$, and $85 \%$, respectively. The results show that the lowest removal efficiency belonged to TOC (52.8\%) and the highest one belonged to chlorophyll (85\%). While the effects of alum in the removal of turbidity, color, TOC, and chlorophyll a in the same state with $\mathrm{pH} 7$ at doses of 5 to $25 \mathrm{mg} / \mathrm{L}$, was $20 \%, 18.4 \%, 7.4 \%$, and $25.5 \%$, 
respectively. Therefore, it can be said that in the second case (pre-ozonation with coagulant), the average removal efficiency of parameters was $70 \%$, but in the first case (pre-ozonation alone), the average removal efficiency of parameters was $43 \%$. Thus, high performance of preozonation with coagulant in the removal of water quality parameters in comparison to ozonation alone has a double effect on the removal of the parameters. The coagulation process makes the colloidal particles unstable by adding coagulants. Ozone be injected into the process prior to the coagulation and flocculation process, which results in increasing the ability to become flocculate. However, since pre-ozonation can be effectively used for the improvement of coagulation efficacy in the drinking water treatment, the pre-ozonation combined with coagulation is proposed as an alternative to conventional coagulation to improve the process of drinking water treatment plant.

\section{Acknowledgements}

This study is extracted from the Ph.D. thesis of the first author, which was conducted at Department of Environmental Engineering, Bushehr branch, Islamic Azad University. The authors would like to gratitude all people who contributed in this study.

\section{Ethical issues}

The authors certify that all data collected during the study are as stated in the manuscript, and no data from the study has been or will be published separately elsewhere.

\section{Competing interests}

The authors declare that they have no competing interests.

\section{Authors' contributions}

All authors participated in the data collection, analysis, and interpretation. All authors critically reviewed, refined, and approved the manuscript.

\section{References}

1. Zemmouri H, Drouiche M, Sayeh A, Lounici H, Mameri N. Coagulation flocculation test of Keddara's water dam using chitosan and sulfate aluminium. Procedia Eng 2012; 33: 254-60. doi: 10.1016/j.proeng.2012.01.1202.

2. Angreni E. Review on optimization of conventional drinking water treatment plant. World Applied Sciences Journal 2009; 7(9): 1144-51.

3. Kazi T, Virupakshi A. Treatment of tannery wastewater using natural coagulants. Int J Innov Res Sci Eng Technol 2013; 2(8): 4061-8.

4. Napacho ZA, Manyele SV. Quality assessment of drinking water in Temeke District (part II): characterization of chemical parameters. Afr J Environ Sci Tech 2010; 4(11): 775-89.

5. Sciban MB, Klasnja MT, Stojimirovic JL. Investigation of coagulation activity of natural coagulants from seeds of different leguminose species. Acta Period Technol 2005; 36: 81-7.
6. Mahmoudi A, Shafahee HA, Roudbari AA. The effects of water ozonation on disinfection by-product formation. International Journal of Health Studies 2015; 1(1): 32-5. doi: $10.22100 /$ ijhs.v1i1.29.

7. Theodoro JD, Lenz GF, Zara RF, Bergamasco R. Coagulants and natural polymers: perspectives for the treatment of water. Plastic and Polymer Technology 2013; 2(3): 55-62.

8. Wetzel RG. Limnology: Lake and River Ecosystems. 3rd ed. San Diego: Academic Press; 2001.

9. Ozone Medicine Research Center (semi-industrial) of Iran. The method of destruction and removal of metals, colors and organic matter with ozone. [cited 2017 Jun 25]; Available from: http://www.ozone3.ir.

10. Van Staden AL. Activated carbon and ozone as supplementary water treatment options at Rietvtei Dam [dissertation]. South Africa: Rand Afrikaans University; 1996.

11. Kale VS. Consequence of temperature, $\mathrm{pH}$, turbidity and dissolved oxygen water quality parameters. Int $\mathrm{Adv}$ Res J Sci Eng Technol 2016; 3(8): 186-90 doi: 10.17148/ IARJSET.2016.3834.

12. McEE JE, Wolf HW. Water Quality Criteria. 2nd ed. California: State Water Quality Control Board; 1963. p.283.

13. Carrim AH. The effect of pre-ozonation on the physical characteristics of raw water and natural organic matter $(\mathrm{NOM})$ in raw water from different South African water resources [dissertation]. Potchefstroom, South Africa: North-West University; 2006.

14. McLachlan DR. Aluminium and the risk for alzheimer's disease. Environmetrics 1995; 6(3): 233-75. doi: 10.1002/ env.3170060303.

15. Issa JA, Babiker MO, Ohaj M, Osman ME, Abdelrahman MA, Abaker AM. Determination of some inorganic constituents of drinking water in zalingei town central darfur state, Sudan. J Sci Technol 2013; 3(12): 1208-14.

16. Beyene HD, Hailegebrial TD, Dirersa WB. Investigation of coagulation activity of cactus powder in water treatment. Journal of Applied Chemistry 2016; 2016: 7815903. doi: 10.1155/2016/7815903.

17. Collivignarelli MC, Abba A, Benigna I, Sorlini S, Torretta V. Overview of the main disinfection processes for wastewater and drinking water treatment plants. Sustainability 2018; 10(1): 1-21. doi: 10.3390su10010086.

18. Camel V, Bermond A. The use of ozone and associated oxidation processes in drinking water treatment. Water Res 1998; 32(11): 3208-22. doi: 10.1016/S0043-1354(98)001304.

19. Morrison S, Venter A, Barnard S. A case study to determine the efficacy of ozonation in purification processes. Water SA 2012; 38(1): 49-54. doi: 10.4314/wsa.v38i1.7.

20. Schneider OD, Tobiason JE. Preozonation effects on coagulation. J Am Water Works Assoc 2000; 92(10): 74-87. doi: $\quad$ 10.1002/j.1551-8833.2000.tb09025.x.

21. Amy GL, Sierka RA, Bedessem J, Price D, Tan L. Molecular size distributions of dissolved organic matter. J Am Water Works Assoc 1992; 84(6): 67-75. doi: 10.1002/j.15518833.1992.tb07377.x.

22. Owen DM, Amy GL, Chowdhury ZK, Paode R, McCoy G, Viscosil K. NOM characterization and treatability. J Am Water Works Assoc 1995; 87(1): 46-63. doi: 10.1002/j.1551- 
8833.1995.tb06301.x.

23. Zandieh M. Decomposing the red reactive in the aquatic environment by combining ozone with UV ray in a bubble column reactor [dissertation]. Kermanshah: University of Razi; 2012. [In Persian].

24. Torabian A, Ghadimkhani A, Rashidi Mehrabadi A, Shokouhi Harandi M, Janbeglu R. Preozonation effect on total organic carbon removal in surface water treatment. J Water and Wastewater 2006; 17(2):2-9. [In Persian].

25. Ghadimkhani AA, Torabian A, Mehrabadi AR. Preozonation and prechlorination effect on TOC removal in surface water treatment. Pak J Biol Sci 2006; 9(4): 708-12. doi: $\quad 10.3923 /$ pjbs.2006.708.712.

26. Masoomi B, Jafarzadeh Haghighi Fard N, Tabatabaei T, Kuhgardi E, Jorfi S. Evaluation of pre-ozonation unit efficiency in turbidity and TOC removal (case study: Kouhsabz water treatment plant). Journal on Water Engineering 2017; 5(2): 91-100. [In Persian].

27. American Public Health Association (APHA). Standard Methods for the Examination of Water and Wastewater / American Public Health Association, American Water Works Association, Water Environment Federation. 20th ed. Washington, D.C: APHA; 1999.

28. Bahrami Asl F, Kermani M, Farzadkia M, Esrafili A, Salahshour Arian S, Mokammel A, et al. Removal of metronidazole from aqueous solution using ozonation process. Journal of Mazandaran University of Medical Sciences 2015; 24(121): 131-40. [In Persian].
29. Sumegová L, Derco J, Melicher M. Influence of reaction conditions on the ozonation process. Acta Chim Slovaca 2013; 6(2): 168-72. doi: 10.2478/acs-2013-0026.

30. Mamba BB, Krause RW, Matsebula B, Haarhoff J. Monitoring natural organic matter and disinfection byproducts at different stages in two South African water treatment plants. Water SA 2009; 35(1): 121-7. doi: 10.4314/ wsa.v35i1.76650.

31. Yan M, Wang D, Shi B, Wang M, Yan Y. Effect of preozonation on optimized coagulation of a typical NorthChina source water. Chemosphere 2007; 69(11): 1695-702. doi: 10.1016/j.chemosphere.2007.06.014.

32. Amirsardari Y, Yu QJ, Williams P. Effects of ozonation and coagulation on turbidity and TOC removal by simulated direct filtration for potable water treatment. Environ Technol 1997; 18(11): 1143-50. doi: 10.1080/09593331808616633.

33. Melin ES, Odegaard $\mathrm{H}$. The effect of biofilter loading rate on the removal of organic ozonation by-products. Water Res 2000; 34(18): 4464-76. doi: 10.1016/S0043-1354(00)002049.

34. Basak S, Ozgun D, Ozdemir S, Cinar O. The inhibition effect of ozonation in textile wastewater. World Journal of Environmental Research 2015; 5(1): 129-36. doi: 10.18844/ wjer.v5i1.96.

35. Geldenhuys JC, Giard E, Harmse M, Neveling K, Potgieter M. The use of ozonation in combination with lime and activated sodium silicate in water treatment. Water Research Commission; 2000. WRC Report No: 446/1/00. 